\title{
Is an Atheist Religion in Austria Legally Possible?
}

\author{
Wilfried Apfalter \\ Member of the Presidium of the Atheist Religious Society in Austria (ARG) \\ Department of Philosophy, University of Vienna, Vienna, Austria \\ wilfried.apfalter@univie.ac.at
}

\begin{abstract}
In the face of widespread opinion holding that atheism is somehow necessarily separated from religion and opposed to it, the question "Is an atheist religion in Austria legally possible?" is both intriguing and challenging, leading to the cutting edge of contemporary studies on law, religion, and state. By providing a close, focused view on the legal framework concerning an example case in the Republic of Austria, the present article revisits this widespread opinion. It argues that this opinion can be challenged from a legal point of view in at least one concrete case, namely that of a growing group of atheists who try to establish an officially accepted, state-registered religious denominational community of atheists: Atheistische Religionsgesellschaft in Österreich (Atheist Religious Society in Austria), or ARG for short. The article discusses this case and concludes that an atheist religion is legally possible in Austria.
\end{abstract}

\section{Keywords}

Atheism - religion - atheist religion - law and religion - religion and state - religion in Austria - religion in the European Union

The discussion about what exactly, in the academic study (or science) of religion(s), can be legitimately communicated as "religion" raises questions of definition and theory of religion. These questions have been on the table since the beginnings of the modern academic study of religion(s). Sometimes they have been its main course, sometimes a side 
dish, a starter, or dessert. And on occasion they were relegated to the wine list or served as an aperitif.

MICHAEL STAUSBERG ${ }^{1}$

The question "Is an atheist religion in Austria legally possible?" is both intriguing and challenging. It is intriguing, because it touches upon a central question of the study of religion(s); ${ }^{2}$ and it is challenging, because it relates atheism to religion, something that not everybody appreciates.

The term "atheist religion" has two sides, "atheist"3 (or atheism) and "religion," and it is an expression that has more than one meaning. It can mean either an atheist religion ("atheistic religion") or a religion from and for atheists.

Atheism has recently become a popular topic in the study of religion. ${ }^{4}$ There is a widespread opinion "that atheism itself is not a religion." Many people

* Note from the Editors: The author of this article is an officer of the Atheist religious society in Austria (ARG) analyzed in this article and leads parts of its legal and public activities. Nevertheless, we concluded that the argument raises interesting questions for our readers and that the analysis offered has heuristic potential. Therefore, we decided to publish the article, taking into account that publication might serve the agenda of the ARG.

1 Michael Stausberg, "There is Life in the Old Dog Yet: An Introduction to Contemporary Theories of Religion", in Michael Stausberg (ed.), Contemporary Theories of Religion: A Critical Companion (2009), 2.

2 I am deeply convinced that the topic of this article is not a trivial one, and I fully agree with Michael Stausberg's evaluation "that the field appears divided about rather fundamental issues, not the least the very category of religion [...]" (Michael Stausberg, "From 1799 to 2009: Religious Experience Reconsidered - Background, Argument, Responses”, 40 Religion (2010), 281).

3 The neoclassical word "atheist" comprises the prefix " $a$ " (the Greek alpha privativum, a negative prefix) and the stem "theist." It means "non-theist" or "not theist." Unless otherwise stated, translations in this article are my own.

4 See, e.g., Armin W. Geertz \& Guðmundur I. Markússon, "Religion is Natural, Atheism is Not: On Why Everybody is Both Right and Wrong", 40 Religion (2010), 152; Jesse Bering, "Atheism is Only Skin Deep: Geertz and Markússon Rely Mistakenly on Sociodemographic Data as Meaningful Indicators of Underlying Cognition", 40 Religion (2010), 166. This is partly due to the fact that " $\mathrm{t}$ ] he percentage of people declaring themselves as religious nones, a category that includes atheists, is increasing worldwide" (Lori G. Beaman, "Freedom of and Freedom from religion: Atheist Involvement in Legal Cases", in Lori G. Beaman \& Steven Tomlins (eds.), Atheists Identities - Spaces and Social Contexts (2015), 40). 
think that atheism is necessarily separated from religion and opposed to it. ${ }^{5}$ My view is different. In this article, I argue that, in at least one case, a general separation or opposition between atheism and religion is not plausible from a juridical point of view. It may be true, however, that this argument applies to a much broader range of cases. Steven Tomlins and Lori G. Beaman described atheism as "a sub-set of non-religion," and understood non-religion as "an umbrella term which includes atheism, agnosticism, and a variety of the related

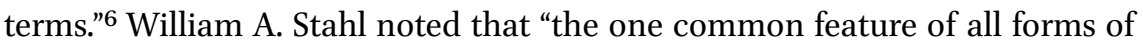
atheism is that it rejects religion." I I propose being both precise and realistic, i.e., open to reality. To the extent that it would be problematic to call theism a religion rather than a concrete instance of it, it would also be problematic to call atheism a religion. Yet, to state that atheism is not a religion does not necessarily imply that a particular form of atheism cannot become a religion. My argument refers to a concrete type of atheism, that of a growing group of individuals who established the Atheistische Religionsgesellschaft in Österreich (Atheist Religious Society in Austria, or ARG for short), ${ }^{8}$ and who seek to gain recognition for it as an officially recognized religious denominational community in Austria.

At its core, atheism is the absence of theism. It is that simple. It is exactly on this basis that in The Oxford Handbook of Atheism, Stephen Bullivant defines "atheism'... as an absence of belief in the existence of a God or gods." ${ }^{9}$ This,

5 See, e.g., Michael Martin, "Atheism and Religion", in Michael Martin (ed.), The Cambridge Companion to Atheism (2007), 217, 230. The growing literature on atheism in studies of religion does not necessarily make this strong claim, but there are also voices that make use of it.

6 Steven Tomlins \& Lori G. Beaman, "Introduction", in Beaman \& Tomlins, supra note 4, 3; see also, e.g., Lori G. Beaman et al., "The Inclusion of Nonreligion in Religion and Human Rights", 65 Social Compass (2018), 43.

7 William A. Stahl, "The Church on the Margins: The Religious Context of the New Atheism", in Beaman \& Tomlins, supra note $4,19$.

8 The ARG generally wants to reach a sustainable equal footing with other religious communities. Therefore, two questions become particularly relevant in the following pages: is an atheist religion possible? And is there an atheist religion established by the ARG?

9 Stephen Bullivant, “Defining 'Atheism”, in Stephen Bullivant \& Michael Ruse (eds.), The Oxford Handbook of Atheism (2013), 13. Stephen Bullivant provided the following definition of atheism: "an absence of belief in the existence of a God or gods. Since it has been a key contention... that the definition of atheism is to be guided by the principle of scholarly utility and not least the extent to which it helps, or hinders, the pursuit of interesting and genuinely illuminating research - then this... can, to a significant degree, be judged by its fruits..." (ibid., 20). In view of section 2 subsection 1 of the currently effective Statutes of the Atheist Religious Society in Austria (ARG, see below), I propose changing "in the existence of a God or gods" to "in the existence of a God or gods as independent actor(s)" or something similar. Likewise, Steven Tomlins and Lori G. Beaman defined atheism as "the position that belief in theism in any form is a false belief" (Tomlins \& Beaman, supra note 4, 5). 
however, does not imply that atheism necessarily means absence of religion, as religion does not necessarily imply theism: there is no obligatory link between atheism and absence of religion, nor is there a contradiction between the terms "atheism" and "religion." Religions can be conceived as question-related cultural systems whose answers "relate to an existential level"10 and, in this way, as "sense-making systems of a certain kind,"11 which, however, may also apply to an atheistic perspective. ${ }^{12}$ My starting point is that atheism is not necessarily the same as non-religion. Perhaps the strongest counterargument against an atheist religion is the fact that many atheists define themselves as non-religious or even anti-religious. But this definition applies only when atheists are in practice non- or anti-religious; it is not valid when atheists define themselves as having a religious conviction or denomination.

I see religion as a cultural construct not only within the study of religion, but also within legal studies. In law, it becomes especially obvious that access to resources that the state grants only to religions is shaped by cultural constructs (i.e., legal norms and court decisions). If we ask "[w] hat kind of labor goes into the construction, maintenance, and contestation of what comes to be deemed as religious,"13 we may see that "[t]he crucial point is that we no longer take 'religion' for granted as a self-evident part of the furniture of the world. We interrogate the category itself, its range of actual deployments, what it does explicitly, but also what it does in less obvious, more concealed ways." ${ }^{14}$ Michael Stausberg noted that "religion can emerge (originate) at any

$10 \quad$ Hans Gerald Hödl, "Study of religion(s), theology and critique of religion(s): An assessment of their relations", 25 Erwägen Wissen Ethik (2014), 68 (German).

11 Ibid.

12 It would not be far-fetched to expect atheists, similarly to others, to deal positively with existential questions (regarding, e.g., suffering, death, meaning in life, etc.). The following pages show that one can hardly deny the ARG existential seriousness or sincerity.

13 Manuel A. Vásquez, "On the Value of Genealogy, Materiality, and Networks: A Response", 42 Religion (2012), 661. See, e.g., Talal Asad, Genealogies of Religion. Discipline and Reasons of Power in Christianity and Islam (1993), 53-54: As "different kinds of practice and discourse are intrinsic to the field in which religious representations... acquire their identity and their truthfulness," defining religion is (also) about dealing with "a particular history of knowledge and power (including a particular understanding of our legitimate past and future) out of which the modern world has been constructed."

14 According to Timothy Fitzgerald, "Critical Religion and Critical Research on Religion: A Response to the April 2016 Editorial", 4 Critical Research on Religion (2016), 308, the study of religion has taken a new direction; its meaning "shifted from the uncritical assumption that some objective and independent phenomena are being observed and described, to the critical task of understanding how the category works and what it does, how and in what circumstances it emerged, and why it seemed necessary to develop a discourse on religions and world religions at all" (ibid., 308-309). Talal Asad (supra note 13,29 ) argued "that there cannot be a universal definition of religion, not only because its 
time, provided certain conditions are met. And these conditions need to be specified by a theory."15 Consequently, "[t]he period since the 1990s has seen an unprecedented proliferation of new theories of religion... and this process does not seem to be exhausted."16

Regarding it as "an emerging phenomenon,"17 Jörg Rüpke defined "religion as the temporary and situational enlargement of the environment - judged as relevant by one or several of the actors - beyond the unquestionably plausible social environment inhabited by co-existing humans who are in communication (and hence observable). What might qualify as 'not unquestionably or immediately plausible' differs from one cultural context to the other and even from situation to situation." ${ }^{18}$ In a nutshell, "a sense of belonging to something greater" can be experienced also by atheists. ${ }^{19}$ From a comparative perspective of the study of religions, to deal with religion is "to observe and narrate an essentially instable object" 20 - often (co-)shaped and stabilized by legal norms. State laws concerning religions often also regulate the access to socially relevant resources. In the words of Linda Woodhead, "Religion is constantly being constructed, as political and legal authorities claim the right to define religion, some social groups vie for the privilege of being counted as religious, others seek to wrest control of the meaning of religion from dominant groups, and still others seek to restrict religion and its sphere of influence."21

What does this instability of religion mean for the study of religions? According to Timothy Fitzgerald, "[i]f religion can mean anything, then it means nothing." ${ }^{22}$ What, then, makes $\mathrm{X}$ (for example, a ritual) a religious $\mathrm{X}$ ? Is it the intentions of the actor? Or is it the cultural sense that some adherents attach to it? "The status that makes things count as something $\mathrm{X}$ can also be challenged; notes/money can become worthless and gods can be dismissed or turned into heritage objects stored in a museum. Their social and objective

constituent elements and relationships are historically specific, but because that definition is itself the historical product of discursive processes."

15 Stausberg, supra note $1,5$.

16 Michael Stausberg, "A New Theory of Religion? Introducing the Review Symposium on Manuel A. Vásquez: More Than Belief (2011)", 42 Religion (2012), 597.

17 Jörg Rüpke, "Religious Agency, Identity, and Communication: Reflections on History and Theory of Religion”, 45 Religion (2015), 358.

18 Ibid.

19 Richard Cimino \& Christopher Smith, "Secularist Rituals in the US: Solidarity and Legitimization", in Beaman \& Tomlins, supra note 4,89 .

20 Rüpke, supra note $17,359$.

21 Linda Woodhead, "Five Concepts of Religion", 21 International Review of Sociology: Revue Internationale de Sociologie (2011), 122.

22 Timothy Fitzgerald, "Critical Religion and Critical Research on Religion: Religion and Politics as Modern Fictions", 3 Critical Research on Religion (2015), 304. 
status remains intentionality-dependent... In this sense (and that includes its materiality), religions are social realities that are constantly created and recreated. This elementary creation of religion... needs to be learned, reproduced and transmitted..."23 Some rites appear in the immediate context of belonging to a religious group. For example, an initiation ritual by which a commitment to a religious denominational group is declared clearly represents a religious ritual. Yet, the statement "Zeus is the father of gods and humans" is a religious statement only if there is an intention to utter it as a religious statement; otherwise, it may be an informative statement about a given belief system or cultural tradition. This is an important difference between a religious statement and, for example, one made by a scholar of religions, ${ }^{24}$ and may lead to the further question: does $\mathrm{X}$ remain a religious $\mathrm{X}$ once it has been established and accepted as a religious $\mathrm{X}$, even if it is done or observed by de facto non-believers?

More than fifty years ago, Melford Spiro suggested to "define 'religion' as 'an institution consisting of culturally patterned interaction with culturally postulated superhuman beings."' 25 This could also apply, for example, to states and other entities that transcend human beings and are "superhuman." While some "accord a kind of 'special' status to religion, and posit it as 'different' to other human cultural products, and other fields of study, it has been argued that the ontological status of 'religious' figures like gods and angels is to all intents and purposes identical to that of figures from popular fictions such as Martians, zombies and cyborgs," so that "these 'persons'..., at a fundamental level," can be conceived as "human inventions, which assist to collapse the artificial distinction between the natural and the supernatural..." ${ }^{26}$

As a socially constructed category, '[ $t]$ he category 'religion' is protected in various ways," ${ }^{27}$ for example, by using the law and the juridical system in

23 Michael Stausberg \& Anna Tessmann, "The Appropriation of a Religion: The Case of Zoroastrianism in Contemporary Russia", 14 Culture and Religion (2013), 445-446.

24 We are currently witnessing a process of social transformation in the field of religion. When this transformation of what is perceived and what is accepted as religion, and how it is lived, becomes visible, it can encourage individuals to ask basic, serious, and followup questions, which should be addressed.

25 Melford E. Spiro, "Religion: Problems of Definition and Explanation", in Michael Banton (ed.), Anthropological Approaches to the Study of Religion (1966), 96.

26 Carole M. Cusack, "Fiction into Religion: Imagination, Other Worlds, and Play in the Formation of Community", 46 Religion (2016), 587 .

27 Timothy Fitzgerald, “'Experiences Deemed Religious': Radical Critique or Temporary Fix? Strategic Ambiguity in Ann Taves' Religious Experience Reconsidered”, 40 Religion (2010), 298. 
general. This issue touches upon the relations between law and religion. ${ }^{28}$ It is helpful to see that " $[t]$ he state's practical need to define these boundaries [between 'religion' and 'non-religion,' which implies much what Thomas Gieryn calls 'boundary work'29], appears to make the state apparatus a performative arena for what Marcus Dressler and Arvind Mandair call 'religionmaking." 30 A relation to transcendence seems to be crucial in this context. For example, imagining supernatural powers with counterintuitive properties is not restricted to a theistic framework, but it is possible also within an atheistic one. ${ }^{31}$ At first sight, this possibility may look like being "if not paradoxical, then at least blatantly counter-cultural"32 (Edward Bailey about "secular religion"), but it surely exists. We may ask ourselves: "Should one set up sharp lines around religion, to ascertain certainly whether a phenomenon is religious? Or should it have ambiguous boundaries, allowing for the unfamiliar and surprising?"33

\section{Defining Religion: the Legal Framework of the European Union}

The normative order of the European Union regarding what counts as "religion" appears in Directive 2011/95/EU of the European Parliament and of the Council of 13 December, 2011, which declares in article 10 number 1 letter b that "the concept of religion shall in particular include the holding of theistic, nontheistic and atheistic beliefs, the participation in, or abstention from, formal

28 If we look for a full analysis of this relationship, we find ourselves exposed to the question of how a legal definition of a term evolves into a broader definition of the term, and vice versa. For the purpose of the current article, it suffices to acknowledge this question.

29 See Thomas Gieryn, Cultural Boundaries of Science: Credibility on the Line (1999).

30 Per-Erik Nilsson \& Victoria Enkvist, "Techniques of Religion-Making in Sweden: The Case of the Missionary Church of Kopimism", 4 Critical Research on Religion (2016), 142, with a quotation ("religion-making") from Marcus Dressler \& Arvind Mandair, Secularism and Religion-Making (2011), 19.

31 Wilfried Apfalter, "Neurotheology: What Can We Expect from a (Future) Catholic Version?", 7 Theology and Science (2009), 163: "The term 'theology' can be used for denoting virtually any scholarly exploration and investigation of a god/goddess or gods or goddesses or divinity in general, respectively; it is obvious that theology, in this broadly open sense, can make sense and can be reasonably practiced even from an atheistic point of view."

32 Edward Bailey, "Implicit Religion", 40 Religion (2010), 271.

33 Anthony J. Blasi, "Definition of Religion", in William H. Swatos, Jr. (ed.), Encyclopedia of Religion and Society (1998), 129. Talal Asad (Formations of the Secular. Christianity, Islam, Modernity (2003), 201), asked: "How, when, and by whom are the categories of religion and the secular defined? What assumptions are presupposed in the acts that define them?" Answering these questions is beyond the scope of the present article, despite their epistemic value. 
worship in private or in public, either alone or in community with others, other religious acts or expressions of view, or forms of personal or communal conduct based on or mandated by any religious belief." ${ }^{34}$

Directive 2011/95/EU could have stated, alternatively, that religious persecution or persecution on religious grounds comprises also the persecution of atheist beliefs and practices. Yet, it unequivocally says that "the concept of religion shall in particular include the holding of theistic, non-theistic and atheistic beliefs... other religious acts or expressions of view, or forms of personal or communal conduct based on or mandated by any religious belief." An example of "theistic" would be "Christian" or "Islamic;" an example of "non-theistic" would be "Buddhist," and an example for "atheistic" would be, well, "atheistic" or "atheist." This clearly indicates that at least from a legal point of view, and at least in the European Union, an atheist religion is possible. Austria is a member state of the European Union.

In Austria, deciding a case of an atheist, the Federal Administrative Court (Bundesverwaltungsgericht) referred to the original version of this directive, namely the European Union Council Directive 2004/83/EC of 29 April, 2004, as referenced in note 34 , spoke of "immediately effective normative specifications that bind all member states of the European Union"35 and of "immediately effective standards of article 10 number 1 letter $b$ of this directive,"36 and therefore applied them directly in its decision.

As noted above, in Austria the ARG seeks to achieve the legal status of an officially recognized religious denominational community. The ARG was founded in 2007. From its inception, it sought full recognition as a religious society in Austria. As its founder, I am deeply involved with the creation of the ARG, the formulation of its statutes, and its dealings with the Austrian legal institutions.

34 "European Union Directive 2011/95/EU of the European Parliament and of the Council of 13 December 2011 on standards for the qualification of third-country nationals or stateless persons as beneficiaries of international protection, for a uniform status for refugees or for persons eligible for subsidiary protection, and for the content of the protection granted (recast)", see Official Journal of the European Union, L 337/9, retrieved 8 Sep. 2019, https://eur-lex.europa.eu/legal-content/EN/TXT/HTML/?uri=CELEX:32011Loo95\&qid=15 $51888757453 \&$ from $=\mathrm{EN} /$. This directive is a revised version. Its wording is the same as that of the European Union Council Directive 2004/83/EC of 29 April, 2004, see Official Journal of the European Union, L 304/12, retrieved 8 Sep. 2019, http://eur-lex.europa.eu/legalcontent/EN/TXT/HTML/?uri=CELEX:32004Loo83\&qid=1478269444452\&from=EN/. Federal Administrative Court decision of 18 March 2015, GZ. L506 1423940-1 (German). 
Its website presents its Statutes (currently in the version of 13 April 2018), with the "purposes and aims of the religious denominational community" stated in section 3 of the Statutes. The section 3 subsection 1 of these ARG Statutes reads as follows: ${ }^{37}$

As a religious denominational community, the "Atheist Religious Society in Austria" has the long-term goal of obtaining full judicial equality and full recognition as a religious society in Austria. We thereby want to open new spaces of cultural participation, and we want to make visible a process of societal change in what is perceived and acknowledged as religion and in how religion is lived.

As noted above, ${ }^{38}$ the ARG seeks to reach a sustainable equal footing with other religious communities in Austria, especially those that are state-registered or legally recognized. It does so not only in relation to these religious communities, but also in relation to the state, the Republic of Austria. Currently, religions in Austria have a special legal position or privilege, with the expectation that they can contribute something that other non-religious actors, such as the state, cannot. The registration of the ARG would create for it the legal status as a religion, which would give the ARG a chance to reach full legal equality in Austria with other religions. Otherwise, full legal equality is not achievable for atheists under the current law. After registration, under the current law, the point of time when the ARG can achieve full legal equality, for example, with the Catholic Church, depends only on the number of members of the ARG.

The question "Is an atheist religion in Austria legally possible?" is asked in the context of Austrian state laws relevant to religious communities and with respect to the registration procedure that the ARG aims to perform. ${ }^{39}$ Both the "Law of 20 May 1874 regarding the legal recognition of religious societies" (AnerkG $)^{40}$ and the Act on the Legal Status of Religious Denominational

37 The Statutes are available at https://atheistisch.at/statuten/. For the website of the ARG, see https://atheistisch.at/ (German).

$38 \quad$ See supra note 8.

39 For a condensed overview of Austrian state laws on religion, see Richard Potz \& Brigitte Schinkele, Religion and Law in Austria (2016). The registration procedure will provide further clarification of what is currently understood by a "religion" by Austrian state laws on religion and will become a precedent. In its concrete form, it will raise an unprecedented challenge to the ARG and to the Office for Religious Affairs. I am entitled to represent the ARG vis-à-vis the Office for Religious Affairs in the registration procedure.

40 Gesetz vom 20. Mai 1874 betreffend die gesetzliche Anerkennung von Religionsgesellschaften, in short form Anerkennungsgesetz, AnerkG, see RGBl. 68/1874 (German). RGBl. = Reichsgesetzblatt (Imperial Law Gazette). 
Communities 1998 (BekGG) ${ }^{41}$ demand filing an application for state registration or recognition with the Office for Religious Affairs at the Federal Chancellery. Both "forms of legal status - legal recognition and state registration - are connected with a certification of the religious character of the community concerned." 42

In the registration procedure sought by the ARG, a central question will be whether or not the ARG represents a religion. In Austrian state law, "religion" is a vague legal term, similar to "science" and "arts." The procedure will require a legal investigation of the material truth, to the degree that it is relevant for the decision about the concrete application. The ARG declares that they want to conduct the procedure transparently, so that the interested public can follow the arguments and evaluate the behavior of both the ARG and the Office for Religious Affairs.

In the contemporary Austrian legal system, the "concept of religion is not defined by current laws." ${ }^{3}$ Therefore, the explanatory materials of the respective laws and the outcomes of jurisdiction, perhaps together with the prevailing legal doctrine, acquire special importance as guidelines for interpreting the legal concept of religion and registration as a religious community. Currently, the two specialized juridical textbooks, Religionsrecht (by Herbert Kalb, Richard Potz, and Brigitte Schinkele) ${ }^{44}$ and Religion and Law in Austria (by Richard Potz and Brigitte Schinkele) ${ }^{45}$ provide an authoritative presentation of the prevailing legal doctrine regarding state laws relevant to religious communities in contemporary Austria.

41 Bundesgesetz über die Rechtspersönlichkeit von religiösen Bekenntnisgemeinschaften, in short form Bekenntnisgemeinschaftengesetz, BekGG, see вGвl. I Nr. 19/1998, as amended BGBl. I Nr. 75/2013 (German). BG Bl. = Bundesgesetzblatt (Federal Law Gazette).

42 Potz \& Schinkele, supra note 39, 47. In Austria, tax exemptions and other privileges of this kind are granted only to recognized religious communities. According to current law (i.e., section 11 subsection 1 letter $d$ of the BekGG), legal recognition requires approximately 17,000 adherents. The Austrian Buddhist Religious Society, for example, has significantly fewer than 17,000 official members (personal communication from Gerhard Weißgrab, President of the Austrian Buddhist Religious Society), but has been legally recognized since 1983 (see infra note 80). For the ARG, however, under the current legal situation, it would not be possible to become legally recognized until it achieves a membership of approximately 17,000 , which is required since the BekGG came into force. Thus, a uniform law on worldview and religion, based on uniform criteria for all, would reduce discrimination.

43 Herbert Kalb et al., infra note 44, 2 (German); in German: "Der Begriff der Religion ist positivrechtlich nicht umschrieben." Cf. Potz \& Schinkele, supra note 39, 52: "No exact legal definition of religion can be said to exist." 
The ARG bases its attempt to become an officially recognized religious denominational community in Austria on the BekGG. ${ }^{46}$ In its first sentence (section 1), the BekGG states that "religious denominational communities in the sense of this federal law are associations of adherents of a religion which are not legally recognized." 47 Thus, according to section 1, this law is applicable only to "associations of adherents of a religion" (Vereinigungen von Anhängern einer Religion).

In section 3 subsection 3, the BekGG demands at least 300 adherents for registration. ${ }^{48}$ In practice, the registration procedure requires at least 300 written membership declarations (i.e., statements in lieu of an oath). On 8 September, 2019, the ARG had a documented membership of about 280 people in all nine provinces of Austria, but predominantly in Vienna, the federal capital and largest city of Austria. Less than $10 \%$ of ARG members were seeking for asylum, due to a personal risk of religious prosecution in the countries they came from, with the ARG helping them to have their atheism recognized by Austrian state authorities and courts of justice. Approximately $77 \%$ of ARG members were men. The distinctly "greater proportion of men to women"49 seems to be a stable, typical feature of organized atheist communities. ${ }^{50}$ Currently, regular monthly meetings take place only in Vienna.

As Richard Potz and Brigitte Schinkele reported, it is according to the established case law of the European Court of Human Rights that the "freedom of thought, conscience and religion," as enshrined in Article 9 of the European Convention on Human Rights, ${ }^{51}$ "is 'one of the most vital elements that go to make up the identity of believers and their conception of life, but it is also a precious asset for atheists, agnostics, skeptics and the unconcerned. The pluralism indissociable from a democratic society, which has been clearly won over the centuries, depends on it. ${ }^{52}$ The right to freedom of religion as guaranteed under the Convention 'excludes any discretion on the part of the state to

46 For basic information about the BekGG, see Richard Potz, "Church and State in Austria 1997", 5 European Journal for Church and State Research - Revue européenne des relations Églises-État (1998), and Richard Potz, "Church and State in Austria 1998", 6 European Journal for Church and State Research - Revue européenne des relations Églises-État (1999).

47 Section 1 BekGG: "Religiöse Bekenntnisgemeinschaften im Sinne dieses Bundesgesetzes sind Vereinigungen von Anhängern einer Religion, die gesetzlich nicht anerkannt sind."

48 Cf. Potz \& Schinkele, supra note 39, 89: "This number was criticized as being too high, especially with regard to new religious movements."

49 Cimino \& Smith, supra note 19, 89.

5o See Cimino \& Smith, ibid., with further literature.

51 In German Europäische Konvention zum Schutze der Menschenrechte und Grundfreiheiten, see BGBl. Nr. 210/1958, as amended BGBl. III Nr. 47/2010 (German).

52 European Court of Human Rights decision of 25 May 1993, Kokkinakis v. Greece, Appl. $14.307 / 88$. 
determine whether religious beliefs or the means used to express such beliefs are legitimate."'53

An a priori exclusion of an atheist religious community from the status of a state-registered religious denominational community means denying access to this status in principle to atheists who commit to their religious denomination. It also means a preferential treatment of theistic (and non-theistic, e.g., Buddhist) religious communities by the Republic of Austria. This is contrary to the neutrality obligation of the state "in matters of religion," 54 which itself is "a consequence of the guarantee of freedom of religion in connection with its commitment to non-discrimination on the basis of religion." ${ }^{55}$ In 2010, the Austrian Constitutional Court stated:

Also, according to the legal practice of the European Court of Human Rights, it is generally not prohibited for a member state to treat different religious groups differently to compensate for actual differences according to article 14 of the European Convention on Human Rights. Article 9 of that Convention, however, because of the substantial benefits conceded to recognized religious communities, provides that the state may remain neutral when exercising competencies, and that within a system of awarding juridical personhood and a specific status to religious groups, all religious communities shall have a fair opportunity of acquiring that status; the established criteria are to be applied in a non-discriminatory way. If there is no objective and rational justification for a different

53 Potz \& Schinkele, supra note 39, 133. Cf. Austrian Constitutional Court decision of 1 December 2010, VfSlg 19240/2010: "The wording of section 4 subsection 1 number 2 of the BekGG suggests that the prosecuted authority is limited to assessing the question of a sufficient presentation of dissimilarity [Unterschiedlichkeit], but is not called to decide in content about the legitimateness of the religious doctrine (cf. European Court of Human Rights, 13 December 2001, Metropolitan Church of Bessarabia and others v. Moldova, Appl. 45.701/99, Z117)." VfSlg = Entscheidungssammlung des Verfassungsgerichtshofs $($ Decisions of the Constitutional Court). Note that, with reference to the US, Winnifred F. Sullivan argued that "legally encompassing the religious ways of people in an intensely pluralistic society is most likely impossible" (Winnifred F. Sullivan, The Impossibility of Religious Freedom (2005), 138). The author noted "the impossibility of fairly delimiting the contours of contemporary religious life" (ibid., 153), and on this basis, the impossibility of guaranteeing religious freedom by law.

54 Potz \& Schinkele, supra note 39, 46: "In as far as the state acts within its central sovereign sphere - i.e., where genuine non-exchangeable state tasks are concerned (for instance, jurisdiction [or when deciding about an application for registration]) - religious neutrality must be realized in its 'distancing' form, avoiding any reference to religious or philosophical beliefs."

Ibid. 
treatment, then it is discriminatory (European Court of Human Rights, 31 June 2008, religious community of Jehovah's Witnesses and others v. Austria, Appl. 40.825/98...). ${ }^{56}$

Thus, self-assignment becomes somehow authoritative. Note that any self-assignment to a concrete religious community presupposes an underlying selfassignment to the field of religion.

The BekGG itself offers no explicit legal definition of religion, ${ }^{57}$ but the Explanatory Notes provide a definition. ${ }^{58}$ The Explanatory Notes, intended to guide juridical interpretation, provide the following short explanation of religion: "Religion: historically grown structure of beliefs whose content can be presented and which interpret the relations of human beings and the world to transcendence, and which accompany them by specific rites, symbols, and action orientations that comply with the fundamental doctrines." 59

The prevailing legal doctrine comments on this definition as follows: "In particular, the phrase 'historically grown structure' needs clarification, because new religious movements that cannot look back on a (long) tradition cannot be excluded prima vista. Also, one probably will not be allowed to set a high benchmark for the conceptual features 'specific rites and symbols.' Cf. the Austrian Constitutional Court decisions VfSlg 2002/1950, 2494/1953, and 2610/1953, whereupon practicing a religious denomination requires a cult, even if it is initially a primitive one."60 Given the increasingly extensive versions of the

56 Austrian Constitutional Court decision of 1 December 2010, VfSlg 19240/2010 (German).

57 Cf. Potz \& Schinkele, supra note 39, 64: "There is no explicit legal definition of religion" in Austrian laws on religion.

$5^{8}$ Explanatory Notes to the Governmental Proposal regarding the BekGG, RV 938 BlgNR 20. GP, printed in Herbert Kalb, Richard Potz \& Brigitte Schinkele, Law of Religious Communities. Recognition and Registration (1998) (German). $\mathrm{RV}=$ Regierungsvorlage (governmental proposal), BlgNR = Beilagen zu den Stenographischen Protokollen des Nationalrats (supplements to the stenographic protocols of the National Council), GP = Gesetzgebungsperiode (legislative period).

59 Explanatory Notes of the BekGG, item III, printed in Kalb et al., ibid., 36 (German); in German: "Religion: Historisch gewachsenes Gefüge von inhaltlich darstellbaren Überzeugungen, die Mensch und Welt in ihrem Transzendenzbezug deuten sowie mit spezifischen Riten, Symbolen und den Grundlehren entsprechenden Handlungsorientierungen begleiten." Cf. Potz \& Schinkele, supra note 39, 52: "The Explanatory Notes of the BekGG 1998 attempt to provide an outline for the purpose of delimiting 'religion' from 'belief' (Weltanschauung), which reads as follows: 'Religion is a historically developed concept of convictions explaining the provenance of mankind and the world with a transcendent reference, including specific rites and symbols giving precepts for acting in accordance with its fundamental doctrines and which is presentable regarding its contents."

6o Kalb et al., supra note 44,4 (German). 
ARG Statutes (e.g., 14 January 2009 v. 13 April 2018), in this concrete case (see section 2 of the ARG Statutes) there exists a "historically grown structure of beliefs whose content can be presented" 61 in the legal sense of the Explanatory Notes of the BekGG.

The Explanatory Notes of the BekGG also provide two further definitions that may be relevant. The first reads: "Religious denominational community [Religiöse Bekenntnisgemeinschaft]: ... The concept used here conforms to the superordinate concept 'religious community' [Religionsgemeinschaft], under which an 'organized community of confessors of one religion' is understood." 62 The second reads: "Religious society [Religionsgesellschaft]: Non-Christian religious community."63 The Austrian legal system uses the term "religious society," for example, as part of the name of the state-registered religious denominational community, Hinduist Religious Society in Austria (Hinduistische Religionsgesellschaft in Österreich, HRÖ). ${ }^{64}$ This suggests that the Office for Religious Affairs allows a state-registered religious denominational community to have the term "religious society" (Religionsgesellschaft) in its name. ${ }^{65}$

Only since 2002 has the Act on Associations (Vereinsgesetz) been applicable also to religious communities. ${ }^{66}$ Therefore, a religious denominational community could not have been expected by law (i.e., by the BekGG, which dates from 1998) to have the legal status of an association, and thereby juridical personhood, when filing its application with the Office for Religious Affairs. In fulfillment of section 11 number 1 letter a of the BekGG, to become legally recognized, the ARG will have to prove 20 years of existence in Austria, with 10

$61 \quad$ Kalb et al., supra note 58,36 (German).

62 Ibid. In a disputation taking place on 5 August, 2009, reported under the title "I feel sorry for you, an atheist" ("Sie tun mir als Atheist ja leid", retrieved 8 Sep. 2019, https:// derstandard.at/1246543699521/Sie-tun-mir-als-Atheist-ja-leid/) between the Catholic Andreas Khol and the atheist Niko Alm, Andreas Khol said: "If the atheists would merge and would say, 'We are a denominational community,' they would have exactly the same rights" ("Wenn die Atheisten sich zusammenschlössen und sagen, wir sind eine Bekenntnisgemeinschaft, hätten sie genau die gleichen Rechte”). Andreas Khol is a university professor of constitutional law and has been a member of the Austrian Parliament for more than two decades, from 2000 to 2002 as Parliamentary Club Chairman (Klubobmann) of the Austrian People's Party (Österreichische Volkspartei, ÖVP), from 2002 to 2006 as President of the Parliamentary National Council (Präsident des Nationalrates).

63 Kalb et al., supra note 58,36 (German).

64 Acquisition of the juridical personhood on 10 December 1998, Office for Religious Affairs decision of 15 April 1999, Gz. BMUkA-13.486/2-9c/99 (German).

65 This is important insofar as the Austrian juridical literature frequently speaks of "churches or religious societies" (Kirchen oder Religionsgesellschaften), which refers only to religious communities recognized by law.

See BGbl. I Nr. 66/2002 (German). 
of these years "in organized form," and with at least 5 of those 10 years as a state-registered religious denominational community. As the Explanatory Notes of the BekGG further indicate in item II, the BekGG should make it possible to gain juridical personhood. Therefore, the BekGG does not demand the existence of juridical personhood (of whatever nature) for a religious denominational community at the time of filing its application. Thus, existing in organized form does not entail juridical personhood as its logical and legal prerequisite. ${ }^{67}$

The prevailing legal doctrine in Austria holds that "[e]very attempt of capturing religion juridically will have to aim also at the three basic elements of religion: the myth explaining the formation of the world, the rite for representing the supernatural by meaningful signs, and the ethos for mediating action-orientations." 68

Taken together, Austrian state laws on religion and the legal framework, as well as the prevailing legal doctrine present four criteria for religion: (a) relation to transcendence, (b) myth, (c) ethos, and (d) rite or ritual. Each one of these deserves close inspection and careful evaluation, and for each, we can ask: "Does the ARG meet the criterion?"

\subsection{Relation to Transcendence}

According to the prevailing legal doctrine, "in the German-speaking academic juridical literature... a religious (or worldview-related) community is understood as being essentially any association of people who want to universally comprehend the whole of the world, who want to realize and evaluate the position of humans in the world on the basis of this comprehensive view of the world, and who are willing to comprehensively attest to this consensus and to act accordingly." ${ }^{\prime 69}$ This does not mean that there is a general requirement for

67 Likewise, a criminal organization (in the sense of organized crime, see section 278a of the Austrian Penal Code, Strafgesetzbuch, B G Bl. Nr. 6o/1974, as amended B G Bl. I Nr. 105/2019) is not bound, according to Austrian state laws, to constitute itself as an association and thereby to acquire juridical personhood; and similarly, such a status is not a condition for being juridically classified and treated as a criminal organization (in the sense of organized crime).

68 Kalb et al., supra note 44, 3 (German); in German: "Jeder Versuch der rechtlichen Erfassung von Religion wird sich auch an deren drei Grundelementen orientieren müssen: dem Mythos zur Erklärung der Gestaltung der Welt, dem Ritus zur Vergegenwärtigung des Übernatürlichen durch sinnenhafte Zeichen und dem Ethos zur Vermittlung von Handlungsorientierungen." Cf. Potz \& Schinkele, supra note 39, 52: "These basic elements correspond with myths that attempt to explain the world, rites for visualizing the supernatural, and the ethos for communicating moral principles."

69 Kalb et al., supra note 44, 2-3 (German); in German: “[...] wird im deutschsprachigen juristischen Schrifttum [...] unter einer Religions- (bzw Weltanschauungs)gemeinschaft im wes- 
religious communities to realize, conceive, and evaluate the whole of the world in all details. Rather, this wish for a comprehensive statement reasonably may concentrate on the aspect of transcendence or some part of it. Section 2 subsection 1 of the ARG Statutes states:

We, the members of the "Atheist Religious Society in Austria," when trying to explain the formation of the world and our position as humans in this world, denominate ourselves in free religious self-determination as "atheists" and

(a) believe that not deities created us humans, but that in each case humans created and/or create their deities (and their narratives and so on), so that all these deities (and so on) in the end always exist only as deities (and so on) that have been created by humans, and

(b)want this religious denomination to be recognized, in an inclusive sense, as a religious denomination in Austria."

Section 2 subsection 1 of the Statutes uses the phrase "so that all these" to make a comprehensive statement. ${ }^{70}$ According to the prevailing academic opinion in contemporary Austria, "if this fundamental conception is based on a personal belief in god or if such a belief is denied but a relation to transcendence $^{71}$ is present, we are dealing with a religion or a religious worldview; if such a relation to transcendence is absent, we are dealing with a nonreligious worldview."72

entlichen jeder Zusammenschluss von Personen, die das Weltganze universell zu begreifen und die Stellung des Menschen in der Welt aus dieser umfassenden Weltsicht zu erkennen und zu bewerten suchen sowie diese Übereinstimmung umfassend bezeugen und danach handeln wollen, verstanden."

70 This subsection also uses the phrase "always only exist as," which is a somehow speculative statement given the possibility that the ARG may not have sufficient knowledge of all deities (and so on). Even if it may be open to empirical falsification, it represents religious belief.

71 We are possibly on safe ground if we understand relation to gods and their narratives as a relation to transcendence.

72 Kalb et al., supra note 44, 3 (German); in German: "Beruht diese Grundauffassung auf einem persönlichen Gottesglauben oder ist bei Ablehnung eines solchen doch ein Transzendenzbezug gegeben, dann handelt es sich um Religion bzw religiöse Weltanschauung, bei Fehlen eines Transzendenzbezuges um eine nicht-religiöse Weltanschauung." In a similar way, Meerten ter Borg once suggested that "[w]e may speak of religion when something super-human is involved” (Meerten ter Borg, "What is Religion?”, in Jan G. Platvoet \& Arie Leendert Molendijk (eds.), The Pragmatics of Defining Religion: Contexts, Concepts and Contests (1999), 401). I understand "super-human" here in the sense of "going beyond" (i.e., transcending) individual humans. 
Thomas Luckmann suggested that "when an experience presents itself as pointing to something that not only cannot be experienced directly (as long as the experiencing self remains in everyday life) but in addition is definitively not part of the reality in which things can be seen, touched, handled by ordinary people, one may speak of the 'great' transcendences."73 "Great transcendences... refer to the boundaries of what is taken for granted in everyday social life." ${ }^{4}$ In exactly this sense, dreams and theories often imply spaces of radically different possibilities or new visions, and therefore great transcendences. ${ }^{75}$ What is taken for granted depends on one's perspective. The concept of an "atheist religion," for example, transcends traditional everyday expectations, and for many it seems somewhat counter-intuitive or paradoxical. Such an assessment, however, is influenced by the viewer's point of view.

The ARG Statutes address different instances of a relation to transcendence. They speak of deities created by humans (section 2 subsection 1 ), make use of reading about deities as a kind of relating to them (section 7 subsection 5), and speak about the not known, about the not experienced, about the desirable (section 2 subsection 4), and about dialogue (section 2 subsection 7). In section 2 subsection 4, the ARG Statutes state: "We recognize that there is much that lies beyond our horizons of knowledge and experience, and we can accept the reality of this not known and not experienced, without demanding ultimate justification. We also recognize that there are desirable things that transcend the horizon of what we have achieved." Furthermore, section 2 subsection 7 states:

Dialogue with others and with different-minded people helps us see and understand our own life in a broader context. By engaging with the worlds of others, we transcend our own horizon of experience.

Section 2 subsection 9 of the ARG Statutes states: "We see death as the irreversible end of our being [unseres Daseins] as active, feeling beings [empfindende Wesen]. Therefore, we see the state of being dead [das Totsein] as a state in which no suffering is felt."

73 Thomas Luckmann, "Shrinking Transcendence, Expanding Religion?", 5o Sociological Analysis (1990), 129. See also, e.g., Thomas Luckmann, "Phenomenological Considerations Regarding Ritual and Symbol”, in Florian Uhl \& Arthur R. Boelderl (eds.), Rituals. Approaches to a Phenomenon (1999) (German).

74 Hubert Knoblauch, "Spirituality and Popular Religion in Europe", 55 Social Compass (2008), 142 .

75 Something that is "only thought," so to say, has a precarious existence. This "something," however, may exist in this way in quite a stable manner. 
Martin Riesebrodt conceives religion as "a complex of practices that are based on the premise of the existence of superhuman powers, whether personal or impersonal, that are generally invisible"76 and calls this "religious premise." 77 Alternatively, we could slightly shift the focus and also call some kind of relation to transcendence "the religious premise." Spirituality in the sense of a relation to the area of transcendence is, in principle, also possible for atheists. There is no sound reason why atheists could not, for example, think about and meaningfully work with cultural narratives that are able to open and expound appropriate and substantially satisfying perspectives on topics of transcendence.

According to the prevailing legal doctrine, "the assessment of the question of transcendence - provided that all other mentioned objective criteria are met - in the end must be left to the self-conception of the given community."78 Thus, the self-conception of the given community should have considerable influence on its juridical assessment. Two comments are in order in this regard. First, the Austrian state always waits for an application (i.e., an action) by a given community before it starts any activity that could lead to recognition. ${ }^{79}$ This guarantees that no community becomes recognized as a religious community against its own will. In this regard, the state treats the self-conception of the community as a relevant factor. Second, Austria was the first state in Europe that officially recognized non-theistic Buddhism as a religion. ${ }^{80}$

Section 2 subsection 1 of the ARG Statutes consists of only one single sentence. If we reduce the sentence to central elements of its subject-predicateobject structure, we read: "We... believe that not ..., but that ..., so that all these deities (and so on) ... exist as deities (and so on) .... ." This structure indicates that if deities are instances of transcendence, a relation to transcendence is

76 Martin Riesebrodt, The Promise of Salvation: A Theory of Religion (2012), 74-75. Translated from German by Steven Rendall, originally published in 2007 as "Cultus und Heilsversprechen: Eine Theorie der Religionen" (German).

77 Ibid., 75 .

78 Kalb et al., supra note 44, 4 (German); in German: "dass die Beurteilung der Transzendenzfrage - sofern die anderen genannten objektiven Kriterien erfüllt sind - letztlich dem Selbstverständnis der jeweiligen Gemeinschaft überlassen werden muss." A relation to transcendence is a delicate criterion because it is hardly verifiable, except for ascertaining whether a relation to transcendence is claimed at all. To my knowledge, in no single case has the existence of a god or goddess or deity (as an independent actor, etc.) been proven to the Office for Religious Affairs. To date, no proof has been required that the alleged transcendence as such really exists as claimed.

79 Cf. section 2 subsection 1 of the BekGG.

8o Legal recognition of the Austrian Buddhist Religious Society (Österreichische Buddhistische Religionsgesellschaft) was granted by statutory instrument (Verordnung) on 13 December 1982 and came into force on 12 February 1983 (в B Bl. Nr. 72/1983). 
present because deities (i.e., supernatural powers) are mentioned explicitly. Moreover, this relation is a clearly positive one ("exist as deities"). ${ }^{81}$ Similarly to this understanding of a relation to transcendence (Transzendenzbezug), the Austrian academic legal discourse regarding the relation to god/religion (Gottesbezug/Religionsbezug) in constitutional preambles refers to the relation to religion as a "reference [Bezugnahme] to the religious dimension"82 and even as a simple "mention [Erwähnung] of the religious dimension." 83 Section 2 subsection 1 of the ARG Statutes contains an unambiguous affirmative statement about the existence of transcendence ("We... believe... that all these... exist as deities...").

A relation to transcendence is not present only when people believe in gods as invisible and independent actors. ${ }^{84}$ It is also present when people refer to gods with the intention to communicate their own religious conviction, even if they do not think of these gods as invisible and independent actors. In principle, different religious convictions are possible, and, accordingly, also different concrete forms of a relation to transcendence. This, I suggest, is also covered by the fundamental right to freedom of religion. ${ }^{85}$

As noted above, section 2 subsection 4 of the ARG Statutes explicitly states that the members of the ARG recognize that there is much that lies beyond the horizon of their knowledge and experience, and that they can accept the reality of this not known and not experienced as well. The subsection also states that members recognize that there are desirable things that transcend the horizon of what they have achieved. Section 2 subsection 7 of the ARG Statutes states that dialogue with others and with different-minded people helps ARG members see and understand their own life in a broader context. By engaging with the worlds of other people, they transcend their own horizon of experience.

Violations of human rights, for example, have a relation to human rights regardless of whether those who commit them believe in human rights or not;

81 The Statutes represent an explicit belief that gods etc. actually do exist. The form of this existence is explained in the theoretically appropriate terms of ontology. This explanation represents a kind of theology.

82 Brigitte Schinkele, "On the Current Discourse About (a New) European and Austrian Constitution", in Michael Bünker (ed.), Protestant Churches and Europe (2006), 66 (German).

83 Ibid., 67.

84 In the religious doctrine of the ARG (see section 2 of the Statutes), gods etc. are represented as human (cultural) products, and humans are presented as evolutionary products. This evolution, in addition to the imagined transcendence of gods, etc., is also something that "transcends" us humans, namely ontogenetically (as individual humans) and phylogenetically (as humankind).

85 See Winnifred F. Sullivan, The Impossibility of Religious Freedom (2005). 
the relation does not depend on the beliefs of those who violate the rights. According to the prevailing legal doctrine, the religiously neutral state must not assess the ontological or theological mode of the existence of transcendence; the state rather has "to abstain from any interpretation or assessment of the theological foundations of the religious doctrine." 86

\subsection{Myth}

Carole Cusack argued that "religion is an example of human participation in explanatory narrative... and is firmly identified as a human cultural product..." ${ }^{\prime 87}$ In section 2 of the ARG Statutes there is mention of deities created by humans and of an ethos developed and negotiated by humans (section 2 subsection 2):

We therefore believe that not deities gave us our ethos but that our ethos in each case has been and is developed [e.g., grounded in - and expressing human biological heritage] and negotiated [e.g., in cultural interactions] by us humans.

Section 2 subsection 5 of the ARG Statutes states:

In terms of our physical life, we see our existence as the transient result of a long chain of evolutionary processes that connect us in many ways with the world we observe. Biological evolution is a process that has spawned and brought forth a multitude of living beings, including us as humankind. It connects us with other living beings. The matter we came from evolved over long periods of time in nuclear fusion processes, which makes us in a figurative sense children of the stars.

Section 2 subsection 9 of the Statutes speaks of "death as the irreversible end of our being as active, feeling beings" and presents "the state of being dead as a state in which no suffering is felt."

86 Kalb et al., supra note 44, 2 (German); in German: "Dabei hat sich der Staat jeder Interpretation oder Bewertung der theologischen Grundlagen der Religionslehre zu enthalten."

87 Cusack, supra note 26, 576, with references to Judith Kovach, "The Body as the Ground of Religion, Science, and Self", 37(4) Zygon (2002), 941, and Maurice Bloch, "Why religion is nothing special but is central", 363 Philosophical Transactions of the Royal Society B: Biological Sciences (2008), 2055. 
Wolfgang Meid spoke of "presumptions of individual thinking humans, which appeared plausible to others, which were able to convince them gradually and which, in the end, were able to result in communities of faith,"88 thus building "the fundamentals of the evolving religions [der sich herausbildenden Religionen],"89 "which are nothing but attempts carried out according to the state of knowledge and the epistemic possibilities [Erkenntnismöglichkeiten], of understanding the genesis of the world and the (inter-) relationships within it." ${ }^{\prime 90}$ Atheists can also ask themselves about the best stories/narratives that we currently have available to understand the world and ourselves.

The Austrian legal system has not yet clarified what a minimum narrative structure of a myth may look like. Wherever a reasonable minimum threshold may lie, classical myths move along somehow abstract meta-levels that transcend personal experience. In a highly condensed form, section 2 subsections 1, 2, 4-5 and 9 of the ARG Statutes describe what we can call a "myth for explaining the formation of the world"91 and it can be conceived as an expression of "beliefs whose content can be presented and which interpret the relations of human beings and the world to transcendence..." ${ }^{92}$ For example, section 2 subsection 2 states that not deities gave humans their ethos but that the ethos of humans has been and is developed and negotiated by humans. The manual Handbuch religionswissenschaftlicher Grundbegriffe ("Manual of Basic Terms/Concepts in the Study of Religion(s)") argues that "[m]ore fruitful than a definition of one necessarily always too narrow concept of mythos/myth appears to be the differentiation of several concepts of myth. If one seeks a common denominator in this diversity, one could define it as the pool of pictures and narratives given to a group."93 The manual Handbuch Religionswissenschaft ("Manual of Religious Studies") speaks succinctly of "beliefs

88 Wolfgang Meid, “On the Etymology and Semantics of German 'Glauben”, in Henning Marquardt et al. (eds.), Anatolica et Indogermanica. Studia Linguistica in Honorem Johannis Tischler Septuagenarii Dedicata (2016), 191 (German).

$89 \quad$ Ibid.

9o Ibid.

$91 \quad$ Kalb et al., supra note 44, 3 (German).

92 Explanatory Notes of the BekGG, item III, printed in Kalb et al., supra note $58,{ }_{3} 6$ (German).

93 Aleida Assmann \& Jan Assmann, "Myth", in Hubert Cancik et al. (eds.), Handbook of Basic Terms/Concepts in the Study of Religion(s) (1998), vol. 4, 179 (German); in German: "Fruchtbarer als eine Definition eines notwendigerweise immer zu engen Mythos-Begriffs erscheint die Unterscheidung mehrerer Mythos-Begriffe. - Wenn man in dieser Vielfalt nach einem gemeinsamen Nenner sucht, könnte man ihn bestimmen als den einer Gruppe vorgegebenen Fundus an Bildern und Geschichten." 
(myths) [Glaubensüberzeugungen (Mythen)]." ${ }^{94}$ Therefore, in the concrete case of ARG there exist "beliefs whose content can be presented and which interpret the relations of human beings and the world to transcendence,"95 and which are provided as a "pool of pictures and narratives."96

\subsection{Ethos}

The third criterion may be summarized as "ethos." ${ }^{97}$ As noted, the ARG Statutes describe an ethos developed and negotiated by humans (section 2 subsection 2 , see above). Section 2 subsection 3 continues:

We consider it desirable to contribute to making a good life become possible for all people, no matter where and how they were born. We consider any form of love based on partnership and any form of living together as a family, whether homosexual or heterosexual, monogamous or polyamorous, with or without children in parental/family care, to be a valuable building block for a good life.

This statement expresses an ethical attitude that not all atheists may agree with; it is an ethical attitude of a particular group of atheists.

As noted, section 2 subsection 7 calls dialogue with others and with differentminded people helpful in seeing and understanding our own life in a broader context; engaging with the worlds of others helps transcend one's own horizon of experience. A specific ethos is reflected, for example, in the participation of the ARG in the IWEo Dialogue Forum "Ethics" of the "Global Ethic Foundation in Austria" (Initiative Weltethos Österreich, IWEO), and in written ARG contributions to it. ${ }^{98}$ This is an ethos of a particular community, that of the ARG, which is open to dialogue. The ARG embodies an atheistic dialogue orientation that does not reject religion from the outset but wishes others to recognize

94 Johann Figl, "Introduction: Study of Religion(s) - Historical Aspects, Contemporary Understanding of the Discipline and Concept of Religion, in Johann Figl (ed.), Handbook Study of Religion(s): Religions and their Central Themes/Topics (2003), 69 (German).

95 Explanatory Notes of the BekGG, item III, printed in Kalb et al., supra note $58,{ }_{3}^{6}$ (German).

96 Assmann \& Assmann, supra note 93, 179 (German).

97 The question of a reasonable minimum threshold for realizing an ethos (i.e., a basic attitude with a certain perspective) remains unanswered from the legal point of view in Austria.

98 Some information about the IwEo Dialogue Forum is available at http://www.weltethos .at/iweo-dialogforum-ethik-iweo/. For the official site of the IWEo, see http://www.wel tethos.at/ (German). 
ARG as a religious community. The behavior of the ARG embodies a particular ethos.

Section 2 subsection 10 of the ARg Statutes states:

We consider it desirable to contribute that, when we die, we leave the world in better shape for future generations than we found it when we were born.

Section 4 subsection 3 of the ARg Statutes determines that "all members, specifically the members of the Presidium, are bound by the Statutes of the religious denominational community if they explicitly act as members and/or organs of the 'Atheist Religious Society in Austria." Section 8 subsection 3 determines that members of the Presidium are obligated to treat the membership of all members of the Atheist Religious Society in Austria as confidentially as possible and states that this obligation extends also to the time after their membership in the Presidium. Section 8 subsection 5 determines that members of the Presidium must contribute to a productive and appreciative working atmosphere within the Presidium.

Section 7 subsection 9 states:

The Presidium can at any time entrust members of our religious denominational community who agree to exercise the function of a presidium assistant or presidium secretary or regional contact person, and can end such entrustment at any time. All presidium assistants, presidium secretaries, and regional contact persons are obligated (a) to treat the membership of all members of the "Atheist Religious Society in Austria" as confidentially as possible; this obligation extends especially to the time after the end of their entrustment; (b) and, to the extent that they discharge their function by working in the Presidium or in the environment of the Presidium, to contribute to a productive and appreciative working atmosphere."

Section 2 subsections 2, 3, 7, and 10, section 4 subsection 3 , section 7 subsection 9, and section 8 subsections 3 and 5 express what may be called an "ethos for mediating action orientations." ${ }^{\text {" } 9}$ At the same time, they point to "action orientations that comply with the fundamental doctrines" in the juridical sense of

$99 \quad$ Kalb et al., supra note 44, 3 (German). 
the Explanatory Notes of the BekGG. ${ }^{100}$ These action orientations are specific to the Statutes of the ARG and comply with its fundamental doctrines (section 2 of the ARG Statutes). Achieving the juridical personhood of a religious denominational community according to the BekGG is covered by section 2 of the ARG Statutes, as the BekGG explicitly demands statutes. In the current legal situation in Austria, the ARG cannot achieve the legal status of a stateregistered religious denominational community without statutes.

Even if the ethos of the ARG does not appear as monolithic as that of some other religious traditions, at least in these traditions' self-understanding of their ethos, it has a shared theoretical basis with them, expressed in section 2 subsection 2. Thus, in this concrete case, there exist specific "action orientations that comply with the fundamental doctrines"101 in the juridical sense of the Explanatory Notes of the BekGG.

\subsection{Rite}

The fourth criterion may be summarized as rite or ritual. The Austrian legal system has not clarified to date what the minimum structure of a rite or ritual must look like. The Austrian scholar of religion and expert in rituals, Gerald Hödl, proposed "to speak of a 'ritual' when a regulated, recurring course of actions transmits a message" 102 so that "if I execute an action regularly and if this action has a symbolic value for me, then it is a (small) ritual."103 Although rituals and rites follow some spatiotemporal order, there is no mandatory requirement for performing them again and again. For instance, joining the ARG is an initiation ritual. The ARG makes this ritual possible by providing the requisite forms, and it is not necessary to join again and again to make it a ritual. Similarly, Catholics are generally baptized only once in their life.

The practices of joining the ARG and the Presidium of the ARG, and of conducting dialogues, which are enacted by members of the ARG, can be understood as being part of the "emergence of religion through shared ideas and experiences." 104

In the view of Martin Riesebrodt, “[r]eligious' actions are those whose meaning is defined by their reference to personal or impersonal superhuman powers... No one practices religion without appropriating forms and

\footnotetext{
1 oo Explanatory Notes of the BekGG, item III, printed in Kalb et al., supra note $58,3_{6}$ (German).

101 Ibid.

102 Hans Gerald Hödl, "Rituals from the Perspective of the Study of Religion(s)", 69 Heiliger Dienst (2015), 227 (German).

103 Ibid.

104 Cusack, supra note 26.
} 
contents." 105 And again: "It is not reflection or discourse that characterize religious practices, but rather the establishment of contact with superhuman powers." ${ }^{106}$ I suggest that we can also count evolution and culture as such superhuman powers, and I can conceive reflection and discourse to be religious practices. Thus, contact with superhuman powers can also be practiced as spirituality, reflection, and dialogue. Section 3 subsection 2 of the ARG Statutes makes the following statement:

We join in a religious denominational community to jointly deal with the questions arising from the religious doctrine mentioned in section 2 . A central purpose is to develop concepts for effective and salutary religious care [Seelsorge], then to put this religious care into practice. As part of the religious care concept, we foresee at the present time that we will want to use concepts such as "temple" and "monastery" for religious care as we understand it.

The Austrian Buddhist Religious Society (Österreichische Buddhistische Religionsgesellschaft) could have been recognized by a special law but was legally recognized by a statutory instrument (Verordnung) relating to the AnerkG. To my knowledge, the Office for Religious Affairs has never questioned this legal recognition. Thus, in the eyes of the Office for Religious Affairs, for decades this AnerkG has allowed, and it is reasonable to assume that it continues to allow, the legal recognition of a non-theistic religious community that has no divine service. We can expect it, therefore, to do the same with respect to an atheistic religious community.

The fact that many religions have $\mathrm{X}$ does not imply that every religion and every new religion must also have $\mathrm{X}$. The Office for Religious Affairs is not entitled to consider typical characteristics of traditional religions as necessary features of a religion.

In section 2 subsection 11 of the Statutes, the ARG presents three rites: (a) a vegetarian rite, (b) a vegan rite, and (c) a pacifist rite:

105 Riesebrodt, supra note 76, 75. As Michael Stausberg says, "one still wonders whether the theory presents an end point or starting point for theorizing about religion. Riesebrodt takes for granted things that other theories seek to explain in the first place" (Michael Stausberg, "Interventionist Practices and the Promise of Religion: On Martin Riesebrodt, Cultus und Heilsversprechen (2007)", in Michael Stausberg (ed.), Contemporary Theories of Religion: A Critical Companion, (2009), 277).

106 Riesebrodt, supra note $76,78$. 
We are aware that the state laws on religion that are currently in force offer special opportunities for making legal allowance for rites. In this context, we believe and wish that it shall be possible for each member (a) to live, at the member's own discretion, in a vegetarian way (vegetarian rite), and (b) to live, at the member's own discretion, in a vegan way (vegan rite), and (c) to live, at the member's own discretion, in a pacifist way (pacifist rite).

These rites present options for a way of life. The decision to live in accordance with these rites is similar to joining a religious order. Typically, not every member of a religious community must join a religious order; joining a religious order is a voluntary, personal decision. The rules of a religious order are valid only for members of the order, but nevertheless claim full religious validity.

Regarding the induction/incorporation of a new member of the Presidium, section 7 subsection 5 of the ARG Statutes gives the following instruction:

The Presidium may at any time induct/incorporate [aufnehmen] members and only members of our religious denominational community into the Presidium. Such a member, with at least one officiating member of the Presidium being present, reads the Statutes in their current version entirely and accurately. The member is then given the opportunity to formulate questions and remarks and to discuss them. The member confirms being ready for induction/incorporation [Aufnahme] by saying: "I have read. I have understood. I'm ready." The member then signs the induction/incorporation protocol, which is witnessed by the signature of the attending members of the Presidium. The witnessing validates the induction/incorporation, and unless otherwise stated in the protocol, takes effect immediately.

Thus, section 7 subsection 5 of the ARG Statutes informs us about what Timothy Fitzgerald called "prescribed procedures (ritual practices)... conducted by special functionaries."107 It describes what can be called a "rite for representing the supernatural by meaningful signs"108 because the ritual of reading the ARG Statutes implies also reading section 2 of these Statutes (i.e., the "presentation

107 Fitzgerald, supra note 27, 297. This touches upon the question: "Which persons are deemed to be 'spiritual ministers' and how far-reaching the seal of confession is, follows from the self-understanding of the respective church or religious community" (Potz \& Schinkele, supra note 39, 180); according to Potz \& Schinkele, ibid., 179, this is the case "irrespective of the legal status of the church or religious community in question."

Kalb et al., supra note 44, 3 (German). 
of the religious doctrine"), with its explicit reference to "deities (and their narratives and so on)." This act of reading, as much as an act of writing or speaking, appears to be an act of representing the supernatural, ${ }^{109}$ performed by meaningful signs (constituting the written text of the Statutes). The name of the ARG is in itself a symbol, ${ }^{110}$ as is the ARG logo, ${ }^{111}$ the text of the ARG Statutes, and the official form for joining the ARG. ${ }^{112}$ Likewise, section 7 subsection 5 of the ARG Statutes describes a specific rite, because it explicitly refers to members of the ARG Presidium and to a concrete occasion: induction/incorporation into the Presidium. The rites or rituals described in the ARG Statutes (joining, induction/incorporation into the Presidium, leaving, etc.) can easily be conceived as specific rites in the legal sense of the Explanatory Notes of the BekGG. ${ }^{113}$ Therefore, it is justified to state that, in the concrete case of the ARG, there exist specific rites and symbols.

The closer characterization of religious denominational communities in section 1 of the BekGG explicitly speaks of "associations" (Vereinigungen), but not of regular meetings or gatherings. ${ }^{114}$ Moreover, the European Union Directive $2011 / 95 / \mathrm{EU}$ (see above) ${ }^{115}$ represents an inclusive approach that is already

109 Note that because religious rituals typically deal with "some kind of relationship to nonordinary agents" (Pierre Liénard \& Ernest Thomas Lawson, "Evoked culture, ritualization and religious rituals", 38 Religion (2008), 158), merely thinking of X possibly creates a kind of relationship with $\mathrm{X}$, at least for a short time, regardless of whether or not, in reality, $\mathrm{X}$ is only culturally constructed or postulated.

110 The name "ARG" itself is a strong symbol that allows for recognizing who and what is meant. A symbol is a recognition sign. In ancient Greek, sýmbolon denotes "something thrown together," as expressed by -bolon ("something thrown") and syn- > sym- ("together"), as for example, the two halves of an object that can be broken into two parts and whose area of contact is so specific that it guarantees easy recognition when the two parts are carefully pieced together again.

111 For a display, see, e.g., the upper left corner of the ARG homepage. Retrieved 8 Sep. 2019, https://atheistisch.at/ (German). There is an interplay between the name "Atheist Religious Society in Austria" (ARG) and the German word $\arg$, which means something akin to "serious," "severe," or "bad."

112 Officially joining the ARG by completing and signing a form is recognizable as joining a religious confessional community. The statements under oaths that are part of the form attest to the high seriousness or sincerity of this act.

113 Cf. Explanatory Notes of the BekGG, item III, printed in Kalb et al., supra note 58, 36 (German).

114 The second subsection of section 278 of the Austrian Penal Code (Strafgesetzbuch, в в вl. Nr. 6o/1974, as amended BGBl. I Nr. 105/2019) is especially instructive. In this subsection, a "criminal association" is defined as "an association of more than two persons, established for a longer period, which aims at one or several crimes... being performed by one or several members of this association." The law does not speak of all members or many members but only of "one or several." It suffices if a single member acts accordingly.

115 See supra note 34 . 
in force. When it says, "either alone or in community with others," it implies that a religion in this sense does not require joint actions of all its members on a regular basis. It is important to acknowledge that not every religion must be realized following the model of a Christian church, where for purely theological reasons, communal celebrations are central. The interpretation and realization of a community life must be left, to a high degree, to each individual religious community. A religious organization dispersed all over the country, which for whatever reason does not conduct meetings in person, is still a religious association. Personal meetings are not essential features of a religion. One can practice religion even in complete isolation, at least temporarily.

Neither the European Union Directive 2011/95/EU, nor the Explanatory Notes of the BekGG, nor the BekGG request an active community with rituals performed together by all members. The European Union Directive 2011/95/EU explicitly speaks of "the participation in, or abstention from, formal worship in private or in public, either alone or in community with others," ${ }^{, 16}$ and the Explanatory Notes of the BekGG speak only of a "historically grown structure of beliefs whose content can be presented and which interpret the relations of human beings and the world to transcendence, and which accompany them by specific rites, symbols, and action orientations that comply with the fundamental doctrines," ${ }^{\prime 17}$ and do not mention any community with joint rites or rituals. ${ }^{118}$

In 1929, the Austrian Constitutional Court referred to the AnerkG by ruling that, "[a]ccording to section 1 of this law, recognition as a religious society is granted to the adherents of a so far not legally recognized denomination, provided that its religious doctrine, its divine service and its constitution do not include anything unlawful or morally objectionable."119 On this basis, the Constitutional Court continued as follows: "From this it can be concluded that the lawmaker has deemed the above-mentioned features (religious doctrine [Religionslehre], divine service [Gottesdienst, literally "service for or to God"] and constitution [Verfassung]) essential for the concept of a religious society."120

\footnotetext{
116 Ibid.

117 See supra note 59 .

118 If an active community with rituals performed together by all its members were to be mandatory for every religion, religion would have to be conceived after the model of theistic religions, especially, on historical grounds, after the model of Christianity.

119 Austrian Constitutional Court decision of 7 December 1929, VfSlg 1265 (German). See Sammlung der Erkenntnisse und wichtigsten Beschlüsse des Verfassungsgerichtshofes, Neue Folge, no. 1265, vol. 9, 1930, p. 245 (German).

Ibid.
} 
The Office for Religious Affairs used this decision as the reason for requiring information about divine services of the applicants, for example, in the case of the "Church of the Flying Spaghetti Monster" (Kirche des Fliegenden Spaghettimonsters, KdFSM). ${ }^{121}$ Therefore, it is realistic to expect that the Office for Religious Affairs would proceed in a similar way in the case of the ARG as well.

It is, however, reasonable to assume that when dealing with an appeal, the Austrian Constitutional Court would abandon its former position, and that the High Administrative Court would not follow the old line. First, the study of religion shows that religion is not synonymous with theism. Second, the European Union Directive 2011/95/EU is effective law also in Austria (see above). Third, according to the prevailing legal doctrine, the juridical answer to the question "Is there a relation to transcendence or not?" depends on the selfconception of the individual group (see above). And fourth, a central function of the AnerkG is to prevent that "anything unlawful or morally objectionable" be put into practice by a legally recognized religious society. This intention is reflected by the BekGG and elaborated in greater detail in section 5 of the BekGG. In section 4, the BekGG explicitly demands statutes in which, among others, a religious doctrine must also be presented, but does not mention any kind of divine service. Nor do the Explanatory Notes of the BekGG mention any such service. The Austrian Constitutional Court decision VfSlg 1265 may be referring only to a theistic religious society. Since at least 1983, with the legal recognition of the Austrian Buddhist Religious Society, ${ }^{122}$ it has been clear that in Austria a religious society without divine services is possible within the legal framework of state laws on religion. The BekGG follows and incorporates this legal development.

Freedom of religion is a firmly anchored right in Austria. The Republic of Austria is not entitled to prescribe concrete forms of a relation to a deity, even if the Austrian Constitutional Court decision VfSlg 1265 might give that impression; the state may not force anybody to be in contact with a misanthropic people-eating deity that a person and others might believe in. Similarly, the Republic of Austria may not prescribe the acceptance of a deity (cf. the Austrian Buddhist Religious Society as a non-theistic religious community). Nor is the state entitled to demand, even from a theistic religious society, performing divine services on a regular basis. Moreover, the state is not entitled to prescribe to a religious community the way in which it may breathe life into its

\footnotetext{
121 See the Office for Religious Affairs' decision of 5 June 2015, GZ. BKA-KA12.056/0002Kultusamt/2014 (German).

122 See supra note 80.
} 
relation to transcendence, and with what frequency. The concrete shaping of the relation of a religious community with any divine entity must be left to the religious community itself. It would be arbitrary to apply, for example, the practices of the Roman-Catholic Church to all other religious communities, and to demand from them daily divine services. According to state law, and following from the right of freedom of religion, the shaping of their personal relations to divine entities is left to the adherents.

\section{$4 \quad$ Conclusion}

It seems that the case of the ARG has the potential, in the words of Hannah Dick, to "mark a significant change in the state's acknowledgement of atheism as a positive form of belief." ${ }^{\prime 23}$ Should the Office for Religious Affairs hold the alternative view that the ARG has no relation to transcendence, no myth, no ethos, and no rite, it would make an argument for this alternative view, based on material truth. This would presumably include attempts at refuting statements presented in this article, and it would include arguments about details of the four criteria presented above. In any case, the Office for Religious Affairs would have to deal in some detail with the legal concept of "religion," as it is currently understood in Austria, when deciding about the ARG application.

Even if it is reasonable to expect that not all instances of atheism may be able to build a religion, we do not imply that no instance of atheism can constitute a religion. Many atheists wish to avoid religion whenever possible, but we have presented here a concrete case, that of the ARG, and have adopted a certain perspective on this particular form of atheism, challenging the opinion that an atheist religion is not possible. The Atheist Religious Society in Austria serves as a concrete example of an atheist religious denominational community. Against this background and within the Austrian and European frameworks, we have good reason for answering the question "Is an atheist religion in Austria legally possible?" in the affirmative.

The legal status of a state-registered religious denominational community would provide the ARG the clarification that, from the point of view of the state, an atheist religion has the same value as other religious approaches. It would create equal opportunities, especially in the legal field, and open the

123 Hannah Dick, "Atheism in Religious Clothing? Accounting for Atheist Interventions in the Public Sphere", 16(4) Culture and Religion (2015), 372. 
way to full recognition by the state, and to equal rights and obligations. On this basis, it is likely that the study of religion and of the philosophy of religion will face a new challenge and be required to broaden and deepen its perspective on atheism and religion. 